Балашова O. В., аспірантка

Національного університету «Острозька акаделія»

\title{
ЕЛЕКТОРАЛЬНА ВОЛАТИЛЬНІСТЬ ЯК ХАРАКТЕРИСТИКА СТАБІЛЬНОСТІ ПАРТІЙНОЇ СИСТЕМИ УКРАЇНИ
}

\begin{abstract}
Анотація. Залежно від рівня стабільності функціонування партійної системи вона може як виступати каталізатором успішної інституалізації демократичних інститутів, так і сповільнювати процес консолідації та вкорінення демократичних правил гри в політичне життя суспільства. Як стверджує М. Педерсен, зміни партійної системи ніколи не $\epsilon$ простими та прямолінійними. Користуючись визначенням Дж. Сарторі, де партійна система - це «система взаємодії, що є результатом міжпартійної конкуренції», він додає, що цю взаємодію та конкуренцію можна спостерігати на різних рівнях, або, іншими словами, це система, що сама по собі $€$ інтерпретованою сукупністю різних підсистем. Коротке відображення змін партійної системи повинно було б охо-
\end{abstract} пити три наступні рівні: парламенту та уряду, партійної організації та електорату. Зміна партійної системи може бути визначена як сукупний набір змін у моделях взаємодії та конкуренції на цих трьох рівнях, а також між ними. Автор стверджує, що на початковому етапі досліджень неможливо охопити всі ці виміри і першочергово варто зосередити увагу на рівні електорату, для чого і запропонував індекс електоральної волатильності. У нашому дослідженні, аналізуючи дані усіх парламентських виборів в Україні періоду незалежності, вирахуємо індекс електоральної волатильності для кожного електорального циклу та спробуємо прослідкувати тенденцію еволюції. Враховуючи мінливість партійного представництва на виборах та застереження науковців щодо ретельності застосування даної математичної формули та можливих обмежень, що з неї випливають, щодо українського зразка пропонується ввести чіткі критерії проведення обрахунків і як наслідок отримаємо дещо модифікований індекс (класичний індекс Педерсена також вважаємо за доречне вирахувати для простеження кореляційних зв'язків). За результатами дослідження, авторка дійшла висновку, що електоральна волатильність в країні знаходиться на досить високому рівні (враховуючи, що допустима межа 15 , тоді як за результатами парламентських виборів 2014 та 2019 років, корегований індекс електоральної волатильності становив 58 та 46 відповідно), що не дає підстав говорити про стабільну чи поготів інституціолізовану партійну систему. Причини такої мінливої електоральної мотивації лежать в усьому спектрі чинників, починаючи від теорії раціонального вибору i закінчуючи когнітивними особливостями сприйняття особою політики. Суспільний запит на «нові» політичні сили та повна зневіра в «старих» лише сприяє зростанню показників електоральної мінливості.

Ключові слова: електоральна волатильність, індекс Педерсена, партійна система, мотиви електоральної участі, вибори.

Постановка проблеми. В рамках біхевіористичного підходу до дослідження політичних процесів [1; 6] особлива увага приділялась вивченню (не)стабільності партійних систем.
Стабільна партійна система класично вважається ознакою зрілої демократії [2; 3]. Нестабільна партійна система може призвести до домінування короткострокових політичних цілей, надати доступ екстремістським кандидатам та політичним партіям, наразити систему національної безпеки як на внутрішні, так і на зовнішні загрози і послабити фундаментальні інститути демократії [4]. Одним із кількісних індикаторів аналізу стабільності чи нестабільності партійної системи є саме індекс електоральної волатильності, що дозволяє проявити латентні характеристики та потенційні тенденції розвитку партійної системи.

Аналіз останніх досліджень проблематики. Досліджуючи процеси демократичної консолідації в країнах центрально-східної Європи, Г. Тока [5] стверджує, що електоральна нестабільність $€$ найважливішим показником наявності чи відсутності стабілізації партійної системи. А. Пшеворський та Дж. Спраг [6] досліджували вплив змін у електоральній поведінці на інституціоналізацію партійної системи. В. Ешер і А. Тарроу [7] визначають волатильність як кінцеві зміни в межах партійної системи внаслідок зміни партійних преференцій окремих виборців. Також дослідники пропонують використовувати показники електоральної волатильності як «незалежну зміну для дослідження здоров'я демократії» [8]. Науковці одностайні в тому, що існує зв'язок між змінами політичного ландшафту партії та процесом демократизації, а стабільна партійна система є ключовим елементом загальної демократичної стабілізації [9].

У дослідженнях нових демократій у Південній Європі та Латинській Америці і Л. Морліно [10], і С. Майнверінг, і Т. Скаллі [11] стверджують, що стабільність партійної системи є необхідною (але недостатньою) умовою для консолідації демократії та багатьох наступних досліджень і пов'язують високий і стійкий рівень волатильності зі слабкістю демократії. Ф.К. Бертоа [8] звернув увагу на ще одну важливу річ, яка додає актуальності дослідженню показників електоральної волатильності, адже, як констатує автор, цей індекс (в даному випадку конкретно індекс Педерсена) використовується не лише як показник змін у голосуванні за конкретні політичні партії, але також і як інструмент аналізу для багатьох інших процесів та явищ, включаючи дослідження «електоральних траєкторій〉 [12], чергування уряду [13], інституціоналізації партійної системи [14], зміни еліти [15], зниження партійної приналежності [16] та стабільності політичного режиму [17].

Серед українських науковців безпосередньо чи опосередковано вплив електоральної волатильності на партійну систему вивчають такі дослідники, як Г. Боднараш [18], Н. Шестак [19], Р. Манайло-Приходько [20] та інші.

Метою нашого дослідження $є$ простеження еволюції показника електоральної волатильності за період незалежності України та спроба визначити можливі причини та наслідки волатильності українського зразка. 
Виклад основного матеріалу дослідження. М. Педерсен [21] визначає електоральну нестабільність як зміну відносної сили політичної партії від одних виборів до інших, а показник, що дозволяс оцінити динаміку електоральних преференцій від виборів до виборів, є індексом електоральної волатильності (українські варіанти перекладу також звучать як індекс електоральної мінливості або індекс електоральної неусталеності [19]).

Отже, запропонований М. Педерсеном індекс електоральної волатильності демонструє мінливість електоральних преференцій від виборів до виборів та вираховується як половина суми модульної різниці в процентах голосів, отриманих партією на двох останніх виборах

$\mathrm{EV}=0,5^{*}|(\mathrm{~A} 1-\mathrm{A} 2)+(\mathrm{B} 1-\mathrm{B} 2) \ldots+(\mathrm{N} 1-\mathrm{N} 2)|$,

де A, B, N - партії, що брали учать у двох виборах;

A1, B1, N1 - результати партій на перших виборах, у відсотках;

\section{A2, В2, N2 - результати других виборів [21].}

Значення індексу знаходиться в межах від 1 до 100. За умов максимально усталених електоральних вподобань індекс мінімальний, тобто $\mathrm{EV}=1$ (допустима межа $\mathrm{EV}=15$ ). Показник індексу волатильності EV > 15 свідчить про неусталені виборчі преференції у період між черговими виборами. Тобто індекс дозволяе простежити динаміку «сили» партії від виборів до виборів.

Хоча індекс застосовується вже більше 40 років, актуальність його не зменшується, а лише зростає (як і число його модифікацій). Як афористично зазначив П. Маєр [13], сучасна криза демократії та політичних партій пояснюється «розлученням» demos (громадяни) та kratos (партії / держава). Саме індекс електоральної волатильності дозволяс оцінити «стабільність» цього зв'язку між громадянами та партіями. Дослідницька увага зараз найбільше приділена його модифікованим варіантам, котрі дозволяють оцінити зміни у парламенті та уряді, акценти окремо робляться на преференції до «старих» та «нових» партій, а також його пояснювальному потенціалі щодо рівня інституціалізації партійної системи.

Недавні дослідження на електоральну тематику, окрім послаблення зв' язків партій з громадянами, виокремлюють ще декілька тенденцій, які впливають на політичну поведінку, зокрема виборчу. Ці тенденції включають зміни в соціальній структурі основних традиційних політичних розколів, появу нових питань порядку денного та нових політичних цінностей та вподобань [22].

Р. Лачат [23] процес дезінтеграції громадян та партій називає феноменом «електорального віддалення» (electoral dealignment ${ }^{1}$ ), що призводить до переоцінки традиційних моделей виборчої поведінки. За цих умов важко констатувати присутність стабільного електорату, оскільки довгострокові фактори, такі як партійна ідентифікація (відповідно до традиційної Мічиганської моделі) чи дотримання цінностей, породжених політичними розколами (відповідно до теорії Ліпсета і Роккана), уже неадекватно описують сучасну ситуацію.

Як наслідок, ослаблення традиційних цінностей, електоральна невизначеність стрімко зростас. Оскільки прихильність виборців до політичних партій зменшується, зростає роль короткочасних факторів, серед яких центральне місце нале-

${ }^{1}$ Цей феномен у політологічній літературі трапляється часто, наприклад, Р. Далтон описує його як «зв'язки, що руйнуються внаслідок соціальної та політичної модернізації...»

${ }^{2}$ Власні розрахунки на основі даних ЦВК жить конкретним когнітивним чинникам. Тут важливу роль відіграють два елементи: рівень політичної «мудрості» (political sophistication) та використання евристики під час прийняття рішень щодо голосування. Існує велика кількість літератури з політичної психології, що показує центральну роль, яку відіграє політична софістика у процесі формування виборчих преференцій. На базовому рівні дослідники під політичною мудрістю розуміють «накопичені знання в певній галузі» [24].

Отже, як бачимо, навіть за умов стабільних демократій важко комплексно пояснити усі передумови та мотиви електоральної волатильності, тоді як у таких перехідних суспільствах, як українське, питання ще більш неоднозначне та потребує різностороннього дослідження.

Отже, спочатку розглянемо деякі особливості методики визначення показників електоральної волатильності для України. У нашому дослідженні ми послуговуємось класичною формулою М. Педерсена, що демонструє змінну електоральних преференцій населення від виборів до виборів. Враховуючи мінливість партійного представництва на виборах та застереження науковців щодо ретельності застосування цієї математичної формули та можливих обмежень, що з неї випливають [8], щодо українського зразка ми пропонуємо ввести такі критерії проведення обрахунків:

1. Враховуємо партії, що за результатами виборів здобули не менше $1 \%$ голосів виборців, адже сумарно вони відображають виборчі преференції 85-97\% електорату². На нашу думку, такий показник, особливо в українських реаліях, забезпечує максимальну репрезентативність.

2. Враховуючи домінуючу до 2012 року блокову участь політичних партій у виборах, намагаємося простежити у відсотковому еквіваленті електоральну популярність саме політичних партій як складників виборчих блоків. Адже блоки зазвичай формувались винятково для участі у виборах, та їм не притаманна стабільність функціонування. Навіть за умови участі виборчого блоку у кількох послідовних виборчих циклах партійні складники у них змінювались.

3. Для розрахунку пропорційної частки кожної політичної партії у складі виборчого блоку послуговуємось даними ЦВК щодо партійного представництва кандидатів у багатомандатних виборчих округах. Виняток становить лише 2007 рік, враховуючи відсутність інформації щодо партійності кандидатів на виборах, ми розраховували пропорції на основі отриманих мандатів у Верховний Раді України 6 скликання.

4. Усі розрахунки здійснено на основі даних по БВО. Винятково з метою умовного зіставлення розрахунок здійснено і для 1998 року (порівняно з 1994). Для аналізу ми оперували партійністю кандидатів, що здобули перемогу в одномандатних округах. Хоча з погляду математики ця операція не несе особливої цінності, проте з погляду комплексного бачення ситуації ми вважали за доречне здійснення такого зіставлення.

5. I останнє, проте найважливіше, вважаємо за доречне дещо видозмінити класичну формулу електоральної волатильності, запропонувавши «нові» політичні партії, що з'являються у парламенті прирівнювати до 0 на попередніх виборах. Подібного роду операція уже застосовувалась українськими дослідниками [20], проте ми рекомендуємо вдаватись до згаданого вище зіставлення винятково для парламентських партій. Класичний індекс несповна описує електоральну мінливість без урахування цього фактору, особливо це актуально щодо виборів 2012, 2014 та 2019 років. 
Електоральна волатильність політичних партій в Україні та інші суміжні показники (1998-2019 роки)

\begin{tabular}{|c|c|c|c|c|c|c|c|c|c|}
\hline \multirow{2}{*}{ 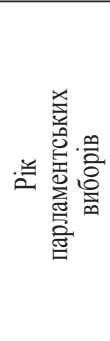 } & \multicolumn{2}{|c|}{$\begin{array}{c}\text { К-ть політичних сил, } \\
\text { що брали участь } \\
\text { у виборах } \\
\text { (за партійними } \\
\text { списками) }\end{array}$} & \multirow{2}{*}{ 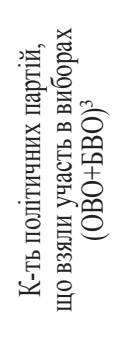 } & \multirow{2}{*}{ 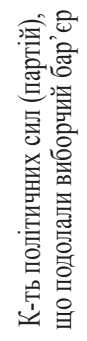 } & \multirow{2}{*}{ 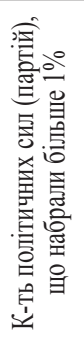 } & \multirow{2}{*}{ 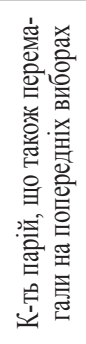 } & \multirow{2}{*}{ 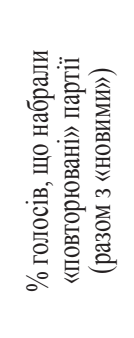 } & \multirow{2}{*}{ 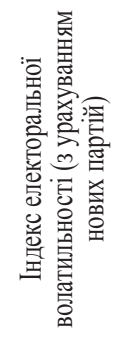 } & \multirow{2}{*}{ 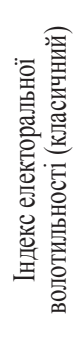 } \\
\hline & 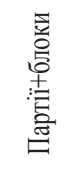 & $\begin{array}{l}\text { : } \\
\text { 善 }\end{array}$ & & & & & & & \\
\hline 1998 & 30 & 40 & 45 & $8(9)$ & $16(23)$ & 6 & 44 & 5.1 & 5.1 \\
\hline 2002 & 33 & 51 & 83 & $6(10)$ & $13(29)$ & 10 & $51.6(58.9)$ & 15.6 & 12 \\
\hline 2006 & 45 & 94 & 94 & $5(11)$ & $11(26)$ & 9 & 81.3 & 37.8 & 37.8 \\
\hline 2007 & 20 & 43 & 43 & 5 & $7(19)$ & 7 & 76.8 & 5.5 & 5.5 \\
\hline 2012 & 21 & 21 & 87 & 5 & 8 & 4 & $69.8(94.2)$ & 22.7 & 10.5 \\
\hline 2014 & 29 & 29 & - & 6 & 12 & 5 & $31.1(86.1)$ & 58.4 & 30.9 \\
\hline 2019 & 22 & 22 & - & 5 & 12 & 6 & $26.5(88.5)$ & 46.4 & 15.3 \\
\hline
\end{tabular}

Джерело інформації: дані з сайту ЦВК

Таблиця 1 демонструє, що електоральна волатильність впродовж всього досліджуваного проміжку часу дуже висока. Показник залежить як від кількості «повторюваних», «сталих» партій, що мінімум на двох послідовних виборах отримують більше $1 \%$ голосів виборців, так і від збалансованості їх показників. Для початку зазначимо, що показник 1998 року дуже умовний, адже для зіставлення ми використовували результати виборів 1994 року, які проводились за мажоритарною системою (у відсотковому еквіваленті вирахували партійну приналежність обраних депутатів). Індекс низький через те, що практично одні і ті ж партії опинились у парламенті, а саме ми зіставляли шість політичних сил: Комуністичну партію України, Народний Рух України, Селянську партію України, Соціалістичну партію України, Українську республіканську партію, Конгрес українських націоналістів. Проте цей індекс недоречно порівнювати з індексами за

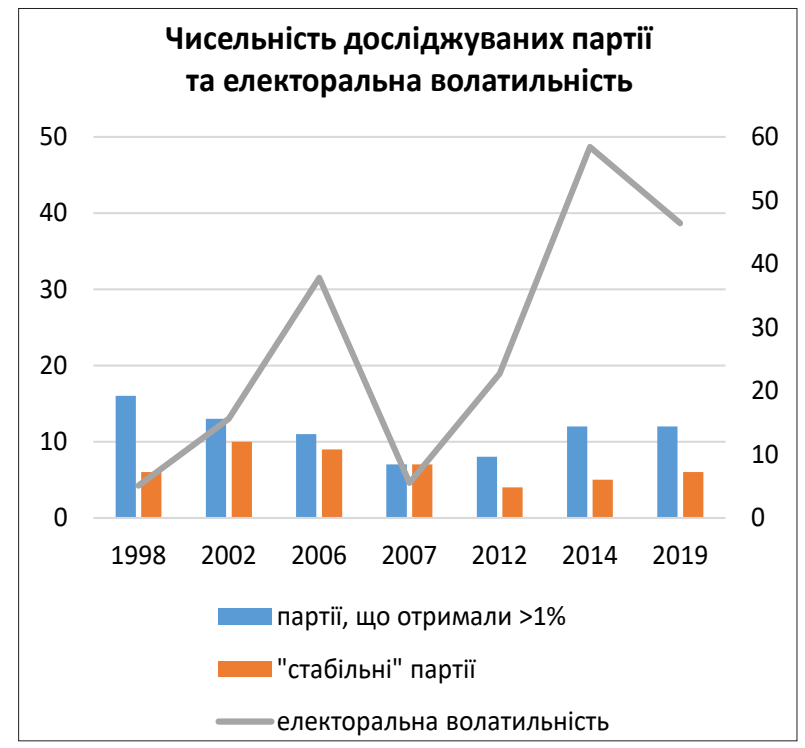

Рис. 1. Співвідношення показників «стабільності» політичних партій та електоральної волатильності

Джерело інформації для розрахунків: дані з сайту ЦВК

${ }^{3}$ Дані взято із книги «Трансформація партійної системи: український досвід у європейському контексті» / За ред. Ю.Якименка. Київ : Центр Разумкова, 2017. 428 с. наступні роки. А отже, єдино низьким показником електоральної волатильності є 2007 рік із значенням 5.5 .

Враховуючи, що ці дострокові парламентські вибори були проведені всього лише за рік після попередніх, електоральні преференції населення змінились мінімально. Як видно із табл. 1, усі сім політичних сил (враховуючи блоковість, це не обов' язково одні і ті ж політичні сили), що подолали $1 \%$ межу, отримали подібний результат і на попередніх парламентських виборах. Дуже важливою закономірністю також $€$ те, що партії отримали приблизно однакову електоральну підтримку населення. Бо ж, наприклад, у 2006 році 311 політичних сил, що подолали 1\% виборчий поріг, 9 партій минулого електорального циклу також набрали більше $1 \%$, проте електоральна волатильність дуже висока - 37.8, що $€$ свідченням того, що, хоча партії практично одні і ті ж, проте їх електоральна підтримка абсолютно відмінна, наприклад, рейтинг КПУ впав 3 майже 20\% (2002 рік) до 3.66\%, рейтинг БЮТ навпаки суттево зріс - $35.7 \%$ ( 2002 рік) до 22.3\%, те ж саме з Партісю регіонів, яка на виборах 2002 року йшла в складі блоку «За єдину Україну», відповідно до пропорційної чисельності ії депутатів могла претендувати на близько $2 \%$ підтримку, тоді як за результатами 2006 року їі електоральна підтримка становила 32.14\%. Саме цей контраст виборчої підтримки і призводить до зростання показників електоральної волатильності. Останні два цикли парламентських виборів 2014 та 2019 років електоральна волатильність максимально висока і становить 58.4 та 46.4 відповідно. Як бачимо, змінювались не лише парламентські партії, а електоральна підтримка партій, що не подолали виборчий бар'єр, теж суттево варіювала. 312 партій, що набрали більше $1 \%$ голосів виборців, в 2014 році лише 5, а в 2019 році - 6 політичних партій були партіями із списку «переможців» (в нашому випадку ті, що набрали більшу 1\% голосів, на двох послідовних виборах).

Своєрідне співвідношення показників «стабільності» політичних партій та електоральної волатильності можна простежити на рис. 1. Хоча однакова кількість (здебільшого одні і ті ж) політичних партій, що впродовж двох послідовних парламентських виборів набирають більше 1\% голосів, не є єдиною визначальною умовою електоральної волатильності, проте вона все ж суттєво впливає. Можна помітити, що чим більша невідповідність політичних сил, тобто чим менша кількість політичних партій характеризується «стабільною» підтримкою електорату, тим вищий загальний індекс електоральної волатильності. 
Також під час опису методологічного базису ми згадували про деякі аспекти коректування індексу до українських реалій. У табл. 1 ми навели також деякі уточнюючі дані, котрі чудово демонструють потребу такої модифікації. Основний момент полягає в тому, що ми пропонуємо «нові» парламентські партії (які не були присутні в парламенті попереднього скликання) прирівнювати до 0. Для цього ми вирахували сумарну електоральну підтримку для досліджуваних політичних партій. Для прикладу, якщо не модифікувати індекс, то відповідно до класичного його варіанту для парламентських виборів 2014 та 2019 років індекс електоральної волатильності вичислюється лише щодо політичних сил, які разом набрали $31.1 \%$ та 26.6\% (відповідно) голосів, що статистично малозначуще, а верифікація таких результатів також сумнівна. Проте за умов модифікації індексу сумарна електоральна підтримка досліджуваних політичних партій вже становить $86.5 \%$ та 88.1\%, що дозволяє більш якісно інтерпретувати отримані дані.

Висновки. Отже, спираючись на отримані показники електоральної волатильності для України, можемо стверджувати, що екстремальна мінливість виборчих преференцій населення негативно впливає на стабільність функціонування партійної системи. Також, враховуючи наші попередні кількісні дослідження [25] показників націоналізації політичних партій та партійної системи України, варто зазначити ще один доволі контраверсійний факт, що випливає із зіставлення емпіричних індексів націоналізації та волатильності. Парадоксальна ситуація спостерігається впродовж останніх двох виборчих циклів - із максимальним зростанням електоральної волатильності зростають і показники націоналізації партійної системи (хоча логічно припустити, що кореляція повинна була 6 бути оберненою). В українському варіанті подій поясненням може бути одночасна «гонка» за «новими» політичними силами та зневіра в «старих», яка і провокує зростання індексу електоральної волатильності, і в той же час стає можливою поява партій 3 максимальними показниками націоналізації (0.89 у БПП та Слуги народу). Ця гіпотеза потребує більш детального дослідження та комплексної аргументації всіх можливих альтернатив.

\section{Jimepamypa:}

1. Балашова О.В. Дослідження партійної системи через призму кількісної методології. Політичне життя. 2018. № 2. С. 5-14.

2. Przeworski, A., Alvarez, R. M., Alvarez, M. E., Cheibub, J. A., Limongi, F., et al. Democracy and development: political institutions and well-being in the world 1950-1990, 2000. volume 3. Cambridge University Press.

3. Putnam, R. D., Leonardi, R., and Nanetti, R. Y. Making democracy work : Civic traditions in modern Italy. 1994. Princeton university press.

4. Sarkar S., Bhusana D. On the Measurement of Electoral Volatility. URL: https://www.isid.ac.in/ epu/acegd2019/papers/ SandipSarkar.pdf.

5. Toka G. Political parties and democratic consolidation in East Central Europe. Number 279. Centre for the Study of Public Policy, University of Strathclyde, 1997.
6. Przeworski A. and Sprague, J. Concepts in search of explicit formulation: A study in measurement. Midwest Journal of Political Science, 1971, pages 183-218.

7. Ascher, W. and Tarrow, S. The stability of communist electorates: evidence from a longitudinal analysis of french and italian aggregate data. American Journal of Political Science, 1975, pages 475-499.

8. Casal Bertoa F. et al. The volatility of volatility: Measuring change in party vote shares / Electoral Studies 50 (2017) 142-156.

9. Tavits, M. The development of stable party support: electoral dynamics in post-communist Europe. Am. J. Polit. Sci. 49 (2), 2005, 283-298.

10. Morlino, L. Democracy between Consolidation and Crisis: Parties, Groups, and Citizens in Southern Europe. Oxford University Press, Oxford, 1998

11. Mainwaring, S., Scully, T. Building Democratic Institutions: Party Systems in Latin America. Stanford University Press, Stanford, CA, 1995.

12. Dassonneville, R., Hooghe, M. Economic indicators and electoral volatility: economic effects on electoral volatility in Western Europe, 2015. 1950-2013.

13. Mair, P. Party systems and alternation in government, 1950-2000: innovation and institutionalization. In: Gloppen, S., Rakner, L. (Eds.), Globalisation and Democratisation: Challenges for Political Parties. Fagbokforlaget, Bergen, 2007, pp. 135e153.

14. Weghorst, K., Bernhard, M. From formlessnesss to Structure? The institutionalization of competitive party systems in Africa. Comp. Polit. Stud. 2014, 47 (12), 1707-1737.

15. Ishiyama, J. Elite volatility and change in North Korean politics: 1997-2010. J. Asian Afr. Stud. 2013, 49 (5), 570-583.

16. Lupu, N., Stokes, S. Democracy, interrupted: regime change and partisanship in twentieth-century Argentina. Elect. Stud. 2010, 29 (1), 91e104.

17. Bielasiak, J. On the Institutionalization of Party Regimes in Emerging Democracies. Working Paper 351. University of Strathclyde, Glasgow, 2001.

18. Боднараш Г. Електоральна волатильність країн Центральної та Східної Європи: порівняльний аналіз. Політологічні та соціологічні студії: Т. Х. Виборчі прочеси в Украӥні та постсочіалістичних країнах: зб. наук. праць / наук. ред. А.М. Круглашов. Чернівці : Букрек, 2011. С. 120-135.

19. Шестак Н. Емпіричні методи дослідження політичних партій та партійних систем. Вісник Львівського університету. Серія філос.-політолог. студіï. Вип. 5, 2014. С. 144-155

20. Манайло-Приходько Р.Ю. Регіональний вимір розвитку та функціонування партійної системи України : дис. ... канд. політ. наук: 23.00.02. Ужгород, 2018. $290 \mathrm{c}$.

21. Pedersen, M. The dynamics of european party systems: changing patterns of electoral volatility. Eur. J. Polit. Res. 1979, 7 (1), 1-26.

22. Dalton, Russell J. and Martin P. Wattenberg (eds). Parties Without Partisans: Political Change in Advanced Industrial Democracies. Oxford : Oxford University Press, 2000.

23. Lachat, Romain. A Heterogeneous Electorate: Individual and Contextual Differences in the Process of Formation of Voting Choices in Germany and Switzerland. PhD Thesis. University of Zurich

24. Fiske, Susan T., Richard R. Lau and Richard A. Smith "On the Varieties and Utilities of Political Expertise", Social Cognition, 1990, 8(1): 31-48.

25. Балашова О.В Націоналізації партійної системи України: вимірювання, динаміка і тренди. Вісник Львівського університету. Серія філософсько-політологічні студії, 2020 
Balashova O. Electoral volatility as an indicator of stability of the party system of Ukraine

Summary. Depending on the level of stability of the functioning of a party system, it can act as a catalyst for successful institutionalization of democratic institutions and slow down the process of consolidation and establishment of democratic rules of a game into the political life of society. According to $\mathrm{M}$. Pedersen, changes in the party system are never simple and straightforward. G. Sartori states the party system is "a system of interaction, which is the result of inter-party competition," he adds that this interaction and competition can be observed at different levels, or, in other words, it is a system that itself is an interpreted set of various subsystems. A brief display of the changes in the party system would cover the following three levels: parliament and government, party organization and the electorate. A change in the party system can be defined as a cumulative set of changes in the interaction and competition models at these three levels, as well as between them. The author claims that it is impossible to cover all these dimensions at the initial stage of research, and it is worth focusing on the electorate level, for which he proposed an index of electoral volatility. In our study, analyzing the data of all parliamentary elections in Ukraine during the independence period, we calculate the electoral volatility index for each election cycle and try to trace the development trend. Given the variability of party representation in the elections and the warnings of scholars about the careful use of this mathematical formula and its possible limitations, related to Ukrainian model, it is proposed to implement clear calculation criteria and as a result we will get a slightly modified index (we also consider it appropriate to calculate the classical Pedersen index to trace correlation connections). Based on the results of the study, the author came to the conclusion that the electoral volatility in the country is at a fairly high level (given that the permissible limit is 15 , whereas according to the results of the parliamentary elections of 2014 and 2019, the corrected index of electoral volatility was 58 and 46, respectively), which does not give us a reason to talk about a stable, or even institutionalized party system. The reasons for such a volatile electoral motivation lie in the whole spectrum of factors, starting from the rational choice theory to the cognitive features of person's perception of the politics. The public demand for "new" political forces and complete disappointment over the "old" ones only contributes to the growth of the electoral variability indicators.

Key words: electoral volatility, Pedersen index, party system, motivation of electoral participation, elections. 